\title{
Convalescent plasma for SARS-CoV-2 infection: win or learn
}

\author{
Enric Contreras-Barbeta ${ }^{1}$, Anna Millan ${ }^{1}$ and Jordi Rello $\mathbb{1}^{2,3,4}$
}

${ }^{1}$ Blood and Tissue Bank of Catalonia, Barcelona, Spain. ${ }^{2}$ Vall d'Hebron Institute of Research (VHIR), Barcelona, Spain. ${ }^{3}$ Centro de Investigacion Biomedica en Red de Enfermedades Respiratorias (CIBERES), Instituto de Salud Carlos III, Madrid, Spain. ${ }^{4}$ Anesthesiology Clinical Research, CHRU Nîmes, Nîmes, France.

Corresponding author: Jordi Rello (jrello@crips.es)

Shareable abstract (@ERSpublications)

Current evidence does not support the use of convalescent plasma in the standard therapy for COVID-19 https://bit.ly/3DGyz6t

Cite this article as: Contreras-Barbeta E, Millan A, Rello J. Convalescent plasma for SARS-CoV-2 infection: win or learn. Eur Respir J 2022; 59: 2102076 [DOI: 10.1183/13993003.02076-2021].

Copyright (C)The authors 2022.

This version is distributed under the terms of the Creative Commons Attribution Non-Commercial Licence 4.0. For commercial reproduction rights and permissions contact permissions@ersnet.org

Received: 26 July 2021 Accepted: 30 Aug 2021

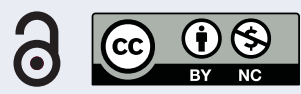

At the end of the 19th century, Emil von Behring (figure 1) demonstrated that serum from horses infected with diphtheria or tetanus was useful in treating people affected by these diseases, inaugurating passive immunisation as a new therapeutic strategy. He received the Nobel Prize in Physiology or Medicine in 1901. This finding opened the door to the use of plasma from convalescent patients to treat infectious diseases; and throughout history, convalescent plasma has been used to treat many diseases, such as Spanish influenza, poliomyelitis, Korean haemorrhagic fever and, more recently, Ebola virus disease and influenza A (influenza H1N1 virus).

The first infusions of convalescent plasma to treat coronavirus infections were performed more than 15 years ago. During the severe acute respiratory syndrome (SARS) epidemics in Asia, the first published articles in 2004 and 2005 showed a reduction in mortality and hospital stay length in the group of patients receiving plasma compared with those receiving standard treatment [1, 2].

The first series of convalescent plasma treatment cases in severe acute respiratory syndrome coronavirus 2 (SARS-CoV-2) patients were published in early 2020 by research groups in Asia. The first such article [3] showed an improvement in clinical and biological parameters after plasma infusion in a series of five critical patients. A faster neutralisation of viral load was also observed [3]. The following preprint article included 19 patients with similar results [4].

In the light of these preliminary first results and in view of the fact that coronavirus disease 2019 (COVID-19) did not have effective aetiological treatment, the European Commission published a guide for obtaining, analysing, processing, storing, distributing and monitoring the use of convalescent plasma [5]. The document covers the use of convalescent plasma exclusively as an experimental therapy and restricts its use to clinical trials or observational studies.

In the USA, the Food and Drug Administration authorised, by an emergency procedure, the use of convalescent plasma in hospitalised COVID-19 patients, restricting its use only to plasma with high titres of anti-SARS-CoV-2 neutralising antibodies. This authorisation received criticism, characterising it as premature and without a basis in scientific evidence [6].

The first publications designed to assess the safety of convalescent plasma concluded that the risk is similar to that of conventional plasma transfusion [7]. Although some authors reported potential risks, such as circulatory overload in critical patients, the effect of the complement and the coagulation factors in an inflammatory and prothrombotic environment and the potential worsening of COVID-19 derived from the contribution of antibodies [8].

The first systematic reviews were then published and agreed in highlighting the lack of scientific evidence to recommend the use of convalescent plasma [9]. When clinical trial results became available, the use of 


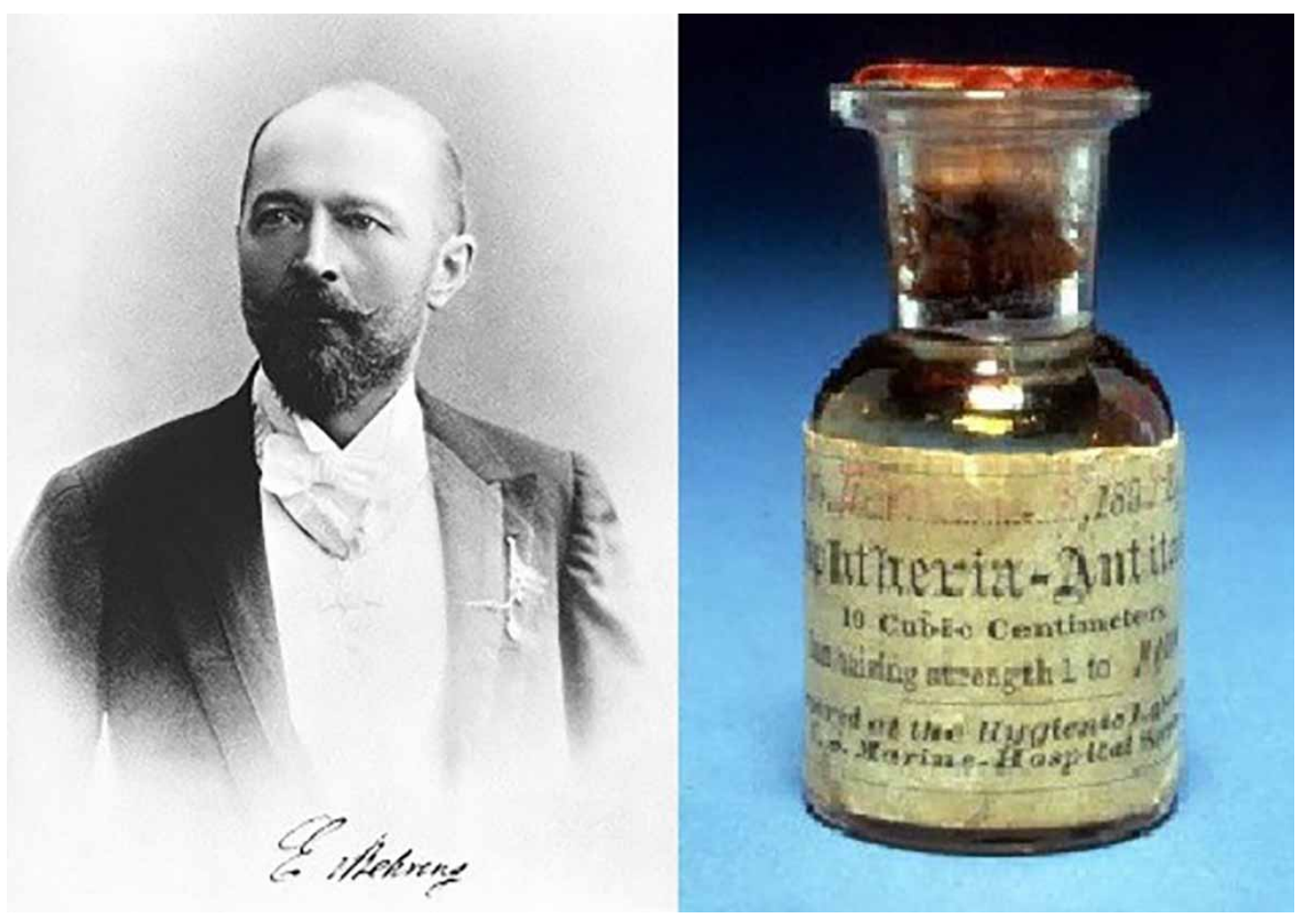

FIGURE 1 Emil Adolf von Behring and anti-diphtheria serum.

convalescent plasma had disappeared from the standard treatment [10] and, simultaneously, recommendations were made against its use in particular groups of patients, for instance, in critically ill COVID-19 patients [11, 12].

Clinical trials such as PLACID [13], PLASMAR [14] and RECOVERY [15] agreed in concluding that convalescent plasma treatment has no impact on mortality in COVID-19 patients. However, other clinical trials pointed to a reduction in the mortality and progression to severe disease with the use of convalescent plasma in specific subgroups of patients, provided that the plasma contained high titres of anti-SARS-CoV-2 neutralising antibodies [16].

A new clinical trial, DAWn-plasma, the results of which are described by Devos et al. [17] in the current issue of the European Respiratory Journal (ERJ), included three important features: early plasma administration, high-dose plasma transfusion and a high titre of neutralising antibodies. Unfortunately, it did not show an impact on mortality or on the evolution to severe COVID-19. Thus, it contributes to reducing the role of convalescent plasma within the available therapeutic arsenal for treating COVID-19 patients [17].

In another study in the current issue of the ERJ, SEKINE et al. [18] reported, in an open-label randomised controlled trial, that neutralising antibodies were present in $83.1 \%$ of patients $(66.3 \%$ of whom were critically ill) at baseline. There was no significant difference in pre-specified outcomes such as 28-day mortality, days alive and free of respiratory support, duration of invasive mechanical ventilation or clinical improvement (61.3\% versus $65 \%$ with standard of care). Median time between onset and infusion was 10 days, no patients received remdesivir and steroids were prescribed in 65\%. The results were similar in both the subgroups of severe and critically ill.

Whereas the current evidence does not support convalescent plasma for standard clinical use, there is an unmet clinical need to identify potential biomarkers and different immune phenotypes for personalised management. It is needed to correlate the response with levels of complement activation, patterns of interferon-stimulated gene expression, viral load, steroids exposure, remdesivir use, monoclonal antibody use, immunocompromised status or severity of respiratory failure.

Moreover, differences in time from symptoms/infection onset to randomisation are extremely important. LiBSTER et al. [16] reported that when administered within $72 \mathrm{~h}$ after onset of mild disease in older adults, 
TABLE 1 Effects on mortality from randomised clinical trials of convalescent plasma versus standard of care for SARS-CoV-2 infection

\begin{tabular}{|c|c|c|c|c|c|c|}
\hline \multirow[t]{2}{*}{ Trial [ref.] } & \multirow[t]{2}{*}{ Country } & \multirow[t]{2}{*}{ Subjects } & \multirow{2}{*}{$\begin{array}{c}\text { Median time from } \\
\text { symptom onset, days }\end{array}$} & \multicolumn{2}{|c|}{ Mortality } & \multirow[t]{2}{*}{ Comments } \\
\hline & & & & $\begin{array}{l}\text { Plasma } \\
\text { group }\end{array}$ & $\begin{array}{l}\text { Control } \\
\text { group }\end{array}$ & \\
\hline PLACID [13] & India & 464 & 4 & $19 \%$ & $18 \%$ & $\begin{array}{l}10 \% \text { dexamethasone } \\
3 \% \text { remdesivir }\end{array}$ \\
\hline PLASMAR [14] & Argentina & 333 & 8 & $10.9 \%$ & $11.4 \%$ & $\begin{array}{l}91.7 \% \text { steroids } \\
29.4 \% \text { ICU }\end{array}$ \\
\hline RECOVERY [15] & UK & 16287 & 9 & $24 \%$ & $24 \%$ & $\begin{array}{c}93 \% \text { steroids } \\
5 \% \text { mechanical ventilation }\end{array}$ \\
\hline $\begin{array}{l}\text { DAWn-plasma } \\
\text { [17] }\end{array}$ & Belgium & 483 & 7 & $16.2 \%$ & $15.9 \%$ & $\begin{array}{c}65 \% \text { steroids } \\
14 \% \text { remdesivir } \\
\text { Progression to mechanical ventilation: } 15 \% \\
\text { versus } 13.5 \%\end{array}$ \\
\hline $\begin{array}{l}\text { NCT04547660 } \\
{[18]}\end{array}$ & Brazil & 160 & 10 & $22.5 \%$ & $16.3 \%$ & $\begin{array}{l}98.8 \% \text { with steroids } \\
61.3 \% \text { versus } 65 \% \text { improvement }\end{array}$ \\
\hline
\end{tabular}

ICU: intensive care unit.

convalescent plasma reduced the risk of progression (relative risk 0.52, 95\% CI 0.21-0.94) to respiratory complications. These potential benefits did not translate into lower rates of patients undergoing mechanical ventilatory support in the other trials [13-17] and, indeed, it might be too late to obtain a meaningful clinical effect $72 \mathrm{~h}$ after symptom onset. Interestingly, the DAWn-plasma trial [17] reflects a very short timeframe of only 1 day between hospital admission and randomisation ( 2 days in the RECOVERY trial [15]), so that it is unlikely that convalescent plasma could have been administered earlier. Therefore, ongoing trials in high-risk patients, such as pregnant women, vulnerable immunocompromised children or solid-organ transplant recipients, should consider a pre-emptive start very early in the infection (within $72 \mathrm{~h}$ of onset), before hospitalisation or in nosocomial acquisition. Comparing this early intervention with monoclonal antibody administration is another unmet clinical need. Severely immunocompromised patients, with refractory infection and who are unable to seroconvert after 3 weeks of therapy, are another group to be assessed for salvage therapy. Indeedn, the evidence reported from current trials (table 1) can help us to learn about the complexity of SARS-CoV-2 infection and the difficulties of its personalised management.

In conclusion, the available evidence, reinforced by the publication of DAWn-plasma and the SEKINE et al. [18] clinical trial, does not support the use of convalescent plasma in the standard treatment of COVID-19. It is likely that, in the near future, more data will appear to help determine whether convalescent plasma transfusion, administered within $72 \mathrm{~h}$ of symptoms onset, may benefit some subgroups of patients with very specific clinical and biological characteristics. These findings also reinforce the need to limit compassionate use of therapies [19], performing well designed randomised clinical trials and restricting therapeutic interventions to those based on evidence.

Conflict of interest: None declared.

\section{References}

1 Soo YO, Cheng Y, Wong R, et al. Retrospective comparison of convalescent plasma with continuing high-dose methylprednisolone treatment in SARS patients. Clin Microbiol Infect 2004; 10: 676-678.

2 Cheng Y, Wong R, Soo YO, et al. Use of convalescent plasma therapy in SARS patients in Hong Kong. Eur J Clin Microbiol Infect Dis 2005; 24: 44-46.

3 Shen $\mathrm{CH}$, Wang Z, Zhao F, et al. Treatment of 5 critically ill patients with COVID-19 with convalescent plasma. JAMA 2020; 323: 1582-1589.

4 Duan K, Liu B, Li C, et al. The feasibility of convalescent plasma therapy in severe COVID-19 patients: a pilot study. medRXiv 2020; preprint [https://doi.org/10.1101/2020.03.16.20036145].

5 European Commission Directorate-General for Health and Food Safety. An EU programme of COVID-19 convalescent plasma collection and transfusion: guidance on collection, testing, processing, storage, distribution and monitored use. 2021. https://ec.europa.eu/health/sites/default/files/blood_tissues_organs/ docs/guidance_plasma_covid19_en.pdf. 
6 Estcourt LJ, Roberts DJ. Convalescent plasma for Covid-19. Authorisation in the US was premature, and a missed opportunity. BMJ 2020; 370: m3516.

7 Joyner MJ, Wright RS, Fairweather DL, et al. Early safety indicators of COVID-19 convalescent plasma in 5000 patients. J Clin Invest 2020; 130: 4791-4797.

8 Dzik S. COVID-19 convalescent plasma: now is the time for the better science. Transfus Med Rev 2020; 34: 141-144.

9 Piechotta V, Chai KL, Valk SJ, et al. Convalescent plasma or hyperimmune immunoglobulin for people with COVID-19: a living systematic review. Cochrane Database Syst Rev 2020; 7: CD013600.

10 Bai CH, Chotirmall S, Rello J, et al. Updated guidance on the management of COVID-19: from an American Thoracic Society/European Respiratory Society coordinated International Task Force. Eur Respir Rev 2020; 29: 200287.

11 Rello J, Belliato M, Dimopoulos G, et al. Update in COVID-19 in the intensive care unit from the 2020 HELLENIC Athens International symposium. Anaesth Crit Care Pain Med 2020; 39: 723-730.

12 Poston JT, Patel BK, Davis AM. Management of critically ill adults with COVID-19. JAMA 2020; 323: 1839-1841.

13 Agarwal A, Mukherjee A, Kumar G, et al. Convalescent plasma in the management of moderate COVID-19 in adults in India: open label phase II multicentre randomised controlled trial (PLACID Trial). BMJ 2020; 371: m3939.

14 Simonovich VA, Burgos Pratx LD, Scibona P, et al. A randomized trial of convalescent plasma in Covid-19 severe pneumonia. N Engl J Med 2021; 384: 619-629.

15 RECOVERY collaborative group. Convalescent plasma in patients admitted to hospital with COVID-19 (RECOVERY): a randomised controlled, open-label, platform trial. Lancet 2021; 397: 2049-2059.

16 Libster R, Pérez-Marc G, Wappner D, et al. Early high-titer plasma therapy to prevent severe Covid-19 in older adults. N Engl J Med 2021; 384: 610-618.

17 Devos T, Van Thillo Q, Compernolle V, et al. Early high antibody titre convalescent plasma for hospitalised COVID-19 patients: DAWn-plasma. Eur Respir J 2022; 59: 2101724.

18 Sekine L, Arns B, Fabro BR, et al. Convalescent plasma for COVID-19 in hospitalised patients: an open-label, randomised clinical trial. Eur Respir J 2022; 59: 2101471.

19 Waterer GW, Rello J, Wunderink RG. COVID-19: first do no harm. Am J Respir Crit Care Med 2020; 201: 1324-1325. 